\title{
Sharing Business Information with Employees
}

\author{
$R$ van der Walt
}

Department of Industrial Psychology, Vista University

\begin{abstract}
The adoption of legislation such as the Labour Relations Act No 66 of 1995 and the Promotion of Access to Information Act No 2 of 2000 has brought about radical change in the process of disclosure of information in South African organisations. The article reviews developments in respect of information disclosure in South Africa and other countries and discusses the effects of the LRA in regard to disclosure of information to trade unions and workplace forums. It then describes a study conducted by the author and discusses the findings. It concludes with pointing out certain shortcomings in the disclosure process and urges managements and the trade unions to work together to improve this important tool for achieving success in organisations and enhancing industrial democracy.
\end{abstract}

JEL J50, J59

\section{INTRODUCTION}

Many changes have taken place since the first democratic elections were held in South Africa in April 1994. An important objective of the new government was to disseminate democratic values throughout South African society. One of the first areas of society earmarked for transformation was the workplace. Amongst other means this was done through legislation such as the Labour Relations Act No 66 of 1995 (LRA 66 of 1995) which was radically different from its predecessor. This paper examines the new democratic values and the effects of information sharing and disclosure which resulted from these new democratic values.

Democracy is undoubtedly one of the major political models in the world. In a true democracy the entire population participates in the government through its elected representatives. On a social level all members of society may share in the benefits of that society but they also have a responsibility to act in the interests of that society. All members may also freely take part in economic activities, provided these are not harmful to the larger society. If democracy is also applied to the world of work, it would mean that employees are entitled to participate in 
decision-making especially in those decisions that have a bearing on them. Productive participation by employees would require that relevant information is shared and disclosed to them for joint decision-making. Information disclosure is, in fact, an essential element in joint decision-making and in labour relations processes such as dispute resolution, collective bargaining and consultation.

The sharing and disclosure of work-related information are means through which industrial democracy can find expression in the workplace. However, not all information which may be disclosed would be of interest to employees, but on the other hand, effective worker participation in decision-making without disclosure of the relevant business information would be impossible. Streek (1994: 90) believes constructive involvement of workers is only possible if they are familiar with the employer's plans and decisions i.e. information is shared between the workers and the employer.

Legislation and judicial rulings dealing with information disclosure emerged at different times in different countries. In the United States it dates back as far as 1936 when the National Labour Relations Board (NLRB) (similar to Commission for Conciliation Mediation and Arbitration (the CCMA) in South Africa) recognised that information disclosure was important for collective bargaining purposes. In the United Kingdom legislation was introduced in 1971 that compelled employers, when requested, to provide trade unions with the kind of information without which collective bargaining would be impeded. Most European countries have a works council system with statutory provisions for disclosure. In Sweden after the Second World War, the disclosure of information was regulated by a voluntary national agreement between the Swedish Confederation of Employers' Organisations (SAF) and the Confederation of Trade Unions (LO). This arrangement was replaced by the Joint Regulation of Working Life Act in 1977 which provides for wide-ranging statutory rights to information (Ballace \& Gospel, 1983).

On an international level organisations such as the International Labour Organisation (ILO), the Organisation for Economic Co-operation and Development (OECD), the United Nations Commission on Transformational Corporations and the European Community/Union have all contributed to a greater awareness of the importance of disclosure of information to the representatives of the workers (Roberts \& Liebhaberg, 1977).

Trade unions view information disclosure as a means of furthering their objectives by extending negotiations and joint regulation into areas that were previously the exclusive domain of management. European unions also regard disclosure of information as a means of broadening industrial democracy (Ballace \& Gospel, 1983). On the other hand some employers regard statutory 
obligation to disclosure to trade unions as a threat to their management prerogative. Their objections are based on the need for commercial secrecy and confidentiality and fear that effective decision-making will be impeded. Other more progressive employers welcome greater disclosure as a channel of communication with their employees.

\section{SHARING AND DISCLOSURE OF INFORMATION IN SOUTH AFRICA}

Since 1994 the South African government has actively attempted to foster a culture of transparency and accountability in public and private bodies by giving effect to the right of access to information. Section 8 of the Constitution "provides for the horizontal application of the rights in the Bill of Rights to juristic persons to the extent required by the nature of the rights and the nature of those juristic persons" as quoted in the Promotion of Access to Information Act No 2 of 2000. Furthermore section 32(1) (a) of the Constitution provides for everyone to have the right of access to information held by the State and section 32(1) (b) " provides for the horizontal application of the right of access to any information held by another person to everyone when that information is required for the exercise or protection of any rights". Section 32(1)(b) means that employees and trade unions now have constitutional support when they demand information from their employers in order to exercise or protect their rights. The Constitution requires the government to enact national legislation to give effect to the rights in Section 32 of the Constitution and this has taken the form of the Promotion of Access to Information Act of 2000.

Landman (1996: 22) is of the opinion that the rationale for disclosure of information can be divided into two aims: the employee-centred aim and the company-centred aim. He writes "Parliament believes that employees and their agents will be able to perform their monitoring functions, exert influence on managerial discretion and make decisions on a higher and more informed perhaps even rational basis if they are provided by employers with relevant knowledge and information." Based on his research Grosett (1997: 37) provides the following reasons for business information disclosure and writes that "employee-centred aims are based on more 'ethical' considerations such as the organisation's responsibility to keep its employees informed and the desirability of employees' representatives to be given information to support the role of joint consultation and other forms of participation in decision-making “.

In dealing with their employers, employees today regard access to business information as essential in order for them to gauge the employer's financial position, as well as the employer's ability to meet their demands. Some 
employers in turn regard the disclosure of business information as a further opportunity to increase their influence and control of the workplace. In this regard Grosett (1997: 37) writes that the aim with information disclosure is to "reinforce management's influence and control of the organization .... achieved by increasing employee involvement and identification with the interests of the organization". However, not all employers view disclosure of information as an opportunity - some see this as a definite threat to their "management prerogative" and fear that it could lead to an escalation in demands from employees.

Grosett's (1997: 38) research of South African organisations found the following benefits of information disclosure as indicated by employers. Employers believe that information disclosure leads to improved employee cooperation because information enhances the employees' understanding of the organisation and decisions made within it. Employers were also of the opinion that shared information leads to improved collective bargaining and reduced conflict. Employers also reported increased employee involvement in decisionmaking because employees had access to relevant information. A further reported benefit was increased levels of job satisfaction.

The disclosure of information in collective bargaining and the consultation process has long found acceptance in other countries as pointed out briefly above. Brand and Cassim (1980: 250) write "The progress of collective bargaining in the United States and Europe has been characterised by the move away from uninformed and irrational bargaining towards sophisticated and intelligent bargaining. In the USA this process has been facilitated by a recognition that, integral to the duty to bargain, is the requirement that an employer furnish relevant information in its possession to the union. The purpose of this is to enable the union to bargain intelligently, to understand and discuss issues raised by the employer's opposition to the union's demands and administer a contract."

Jordaan (1996: 1-2) quoting a report issued by the Advisory, Conciliation and Arbitration Services in the UK writes that a lack of information has been shown to handicap the ignorant party when it comes to the bargaining and consultation process. Automatic disclosure of information to works councils in Germany and the Netherlands is common practice.

The International Labour Organisation(ILO) also recommends that disclosure of information should be part of the collective bargaining process. The ILO's Collective Bargaining Standards Recommendation 163 (1981) reads "measures adapted to national conditions should be taken, if necessary, so that parties have access to information required by meaningful negotiation". 
The need for the development of a culture of information disclosure in South Africa must be seen against the background of a system of government which prevailed for decades and over time resulted in a secretive and unresponsive culture in public and private bodies and which in turn led to abuse of power and even to human rights abuses.

The provisions for information disclosure contained in the Labour Relation Act No 66 of 1995; the doctrine of discovery in law practice, i.e. the obligation on opposing sides to disclose documents that they may have in their possession and the Constitution of the RSA have all contributed to the development of a culture of information disclosure. Johannessen (1995: 45) identified the following reasons for access to information under section 23 of the Constitution of the Republic of South Africa Act 200 of 1993 (the Interim Constitution): Access to information is a right identified in the chapter on fundamental human rights in the Constitution. Allowing citizens to obtain information is an essential part of democratic participation and the free flow of information supports the participatory form of democracy. Access to information encourages accountability in a democracy and also encourages better administrative decisions.

The reasons for gaining access to information mentioned above, reflect the importance of information disclosure in any constitutional democracy. This right to access to information is of such importance that it is specified in the final Constitution. Section 32 of the Constitution of South Africa Act No 108 of 1996 deals specifically with this very important right. In his commentary on section 32, Devenish (1998: 80) writes "Its inclusion endorses the pervasive theme of accountability and transparency of government and administration that runs like a golden thread through the entire Constitution and forms part of a new political morality“. It follows that without disclosure, employees would find it impossible to hold employers accountable for actions that are detrimental to employee interests.

In South African labour law the right to disclosure of information was in the past advanced through the principle of good faith bargaining and the Industrial Court decisions regarding retrenchment. Under the LRA 28 of 1956 the unfair labour practice jurisdiction of the Industrial Court was utilised to induce parties to the bargaining process to engage in meaningful bargaining. In addition, the Industrial Court was able to order access to an employer's premises and the disclosure of relevant information. Some years ago in the Atlantis Diesel Engines v NUMSA case (1995) the Labour Appeal Court dealt with the matter of good faith bargaining and disclosure of information to the trade union when retrenchments were considered. Kahn-Freund (1997b: 21) has written that "Negotiation does not deserve its name if one of the negotiating parties is kept in 
the dark about matters within the exclusive knowledge of the other which are relevant for agreement.“

\section{THE LRA NO 66 OF 1995 AND ITS EFFECTS ON SHARING AND DISCLOSURE OF INFORMATION}

Disclosure of information is provided for in section 16 in order for the LRA to achieve its objectives of promoting collective bargaining and employee participation. Section 16(1) specifies that disclosure of information can only be claimed by a majority union. Minority unions may however act together to achieve a majority and then exercise their right to disclosure. Section16(2) requires that the employer must disclose to a trade union all relevant information. Du Toit et al. (2000: 176 and 1998: 114) under the heading "Disclosure of Information", write that "Once a union has acquired this right, the onus is on the employer to disclose the required information, even in the absence of any request from the union."

In this context, "this right" means the trade union concerned achieving representative status. The "required information" refers to disclosure of relevant information to the union that will allow its representatives to effectively perform their functions and enable it to engage effectively in consultation and collective bargaining in terms of the relevant sections of the LRA.

The spontaneous disclosure of information by employers during collective bargaining and participation by employees in decision-making may be the action that is required to improve and strengthen the trust relationship between employers and trade unions in South Africa,

Successful consultation and joint decision-making processes depend largely on the knowledge the parties have about the issues being discussed. It is for this reason that the legislature has granted Workplace Forums (WPFs) the right to information in terms of section 89 of the LRA. The employer must disclose to the Workplace Forums all relevant information that will allow the Workplace Forums to accomplish effective consultation and joint decision-making. Disclosure of information is mandatory and therefore the Workplace Forums need not first have to request the information specified in the relevant sections of the Act. According to section 89(1) the disclosure is intended to allow the Workplace Forums to take part effectively in consultation and decision-making. It therefore seems logical that such information should be made available before these processes begin in order to allow parties time to prepare. 
An employer with a functioning Workplace Forum has to disclose all relevant information. The relevance is determined by reference to the matters listed for consultation in section 84 and for joint decision-making in section 86 . The Workplace Forums may request further disclosure except in respect of information that is legally privileged and information that cannot be disclosed as such disclosure would contravene the law or an order of the court. Disclosure of information that may cause substantial harm to an employee or employer and private and personal information is also excluded.

\subsection{Relevance of information}

Everingham (1991: 217) suggests that, in general, the following information should be disclosed: Information on the financial status of the organisation; information on absenteeism, industrial relations and productivity; and lastly, information on the employees' contribution to the planning of the organisation's future. This suggestion includes the typical information found in annual reports of companies. It is doubtful whether disclosure of this type of information which is designed to meet the requirements of the shareholders will contribute to more constructive collective bargaining and greater employee participation in decision-making .

Based on the research of information disclosure to employees, Grosett (1997: 39-40) lists the following items of information for disclosure: productivity information; information on morale; information on wages and benefits; safety information; information on company performance; information on wealth sharing and information on the organisation's future.

In regard to disclosure to representative trade unions under section 16 of the LRA, the question of whether or not information is relevant is determined with reference to the circumstances of each case. Furthermore the relevance of information must be determined by the purpose for which it is sought and it must be pertinent to the issues under discussion.

According to section 16(2) the information must be relevant to the duties to be performed by a trade union representative or a shop steward which include such duties as representing employees in grievance and disciplinary hearings; monitoring the employer's compliance with provisions of the Act and collective agreements and reporting alleged contravention of workplace-related provisions of the former; and to perform any other functions agreed to between the trade union representative(s) and the employer. Section 16(3) provides for the disclosure of information so as to allow the trade union to engage effectively in consultation or collective bargaining. 
It is clear that from the preceding review that disclosure and sharing of information play a crucial role in industrial relations in most industrialized countries. As a developing and newly industrialized country, South Africa has securely anchored democratic ideals in its constitution as well as in its labour legislation such as the Labour Relations Act. In order to obtain some idea of the extent to which these ideals have found practical application the writer conducted a study in a number of organisations to establish this. The findings are discussed in the next section.

\section{RESEARCH METHOD AND RESULTS}

\subsection{Research method}

Miles and Huberman's $(1984 ; 1994)$ approach to qualitative analysis is the approach employed in the current study. This approach views data analysis as concurrent flows of activity: data collection, data reduction, data display and conclusion drawing/verification. As a result of the interactive nature of the model data reduction and data display could take place concurrently.

\subsubsection{Data collection}

A number of data collection methods were employed in the research referred to, namely, a literature study, a survey questionnaire and in-depth interviews within the qualitative research tradition.

An extensive investigation was undertaken in order to obtain background information for the execution of the research. The second source for data collection was the seven cases which eventually agreed to participate in the study. These cases are members of the agricultural research (case A), the tertiary education (case B), the private security (case C), the manufacturing (case D), the research and development (case E), the private hospital (case F) and the armaments (case G) sectors of the economy. All seven of these cases were located within the Gauteng Province.

To meet one of the criteria of good qualitative research, namely generalizability triangulation of multiple sources of data was applied, as suggested by Lincoln and Guba (1985: 20). Each organisation that indicated its willingness to participate in the study, was requested to have two questionnaires completed, one by management representatives and one by worker representatives. All the management respondents were requested to give the view of management and the shop stewards/worker representatives the views of the workers in their respective organisations. In other words, multiple views were obtained in each 
case as well as multiple views across different cases in various sectors of the economy.

Where possible available agendas, minutes of meetings and any other documents related to inter-action between management and workers were also obtained. Further data for analysis were obtained from in-depth interviews with respondents who were amenable to requests for explanatory data.

\subsubsection{Data reduction}

This component of the qualitative analysis process refers to selecting and transforming the "raw" data that appear in written field notes or sources of data that could be utilised for research purposes. Data reduction occurs continuously throughout the duration of any qualitative oriented project. In the qualitative analysis process this often starts when a researcher decides which conceptual framework, which sites, which research questions and which data collection approaches to utilize. Data reduction further entails such activities as making summaries, coding, eliciting themes, making data clusters, partitioning data and writing memoranda. Data is further reduced through focussing and bounding the research and generally consists of building a conceptual framework, formulating research questions, sampling and instrumentation (Miles \& Huberman, 1984: $36)$.

A conceptual framework explains either graphically or in a narrative form, the main dimensions to be studied - the key factors or variables and the presumed relationships. A framework can be rudimentary or elaborate, theory driven or commonsensical, descriptive or causal. Using the method suggested by (Miles \& Huberman, 1984: 28; 1994: 18) a conceptual framework was developed for the study.

From the literature studied and current labour relations practice in South Africa, four very specific areas of industrial democracy were chosen as focus areas of which disclosure of business information is one. Disclosure of business information served as the research question of the study, with several subquestions which formed part of the survey questionnaire.

The qualitative researcher encounters the same dilemma as the quantitative researcher in that not all facets of an important problem or social phenomenon can be studied.

The answer to deciding which parameters to include in a study is derived from the nature of the study itself. Sampling in the qualitative research paradigm may involve decisions about which people to observe or interview as well as those 
settings, events and social processes that to should be included in the study. The conceptual framework and research questions dictate the foci and boundaries within which samples are selected.

In the case of the current study the sampling activity commenced with reference to a report of the Commission for Conciliation, Mediation and Arbitration (CCMA) which is the institution created by the LRA of 1995 inter alia to facilitate the establishment of Workplace Forums (WPFs). WPFs are the vehicle of choice to institutionalise industrial democracy in South African workplaces, with advancement of industrial democracy being one of the primary objectives of the LRA of 1995.

In terms of chapter $\mathrm{V}$ of the LRA, all trade union organisations that wish to establish a WPF have to apply the CCMA. Unfortunately, not all applicants have thus far fulfilled all the statutory requirements for registration and consequently failed in establishing statutorily recognised WPFs. Wood and Mahabir (2001: 241) have also pointed out the sparsity of Workplace Forums.

All the applications received are registered by the CCMA according to the nine provinces and are given corresponding case numbers. For purposes of the current study, the Gauteng Province was chosen as the setting of the investigation as it is the province with the greatest economic activity. In the CCMA report available at the time, seventeen cases where registered for the Gauteng Province. One of the cases registered had incomplete organisation and contact details which rendered that particular case unusable for research purposes.

Of the original sixteen cases that were registered with CCMA only two organisations agreed to participate in the study. Reasons for the nonparticipation of the sixteen original cases range from some organisations were no longer in business, committed to other research to not interested in participating in the study. As it was felt that two cases were too few for even a qualitative study it was decided to approach other organisations that were subsequently placed on the CCMA's register or met the requirements for registration but decided not to apply for registration for various reasons. This second attempt added another five cases to the study.

In the current study the data from the questionnaires was reduced through the following steps. The data from each questionnaire was analysed and summarised to build one worksheet with responses of the management and the trade union/worker representatives for each organisation. Relevant additional information from agendas, minutes of meetings, memoranda etc. were also 
recorded on the worksheets. From the worksheets the data was transferred to displays such the various tables and lists used in the study.

\subsubsection{Data display}

The first step to display the data in the current study was build a cross-case compilation of the management and the worker views on the four selected aspects of industrial democracy. Miles and Huberman (1994: 178) refer to these cross case displays as meta-matrixes. They are master charts that gather descriptive data from each of several cases in a standard format. Table 1 illustrates the result of this step.

Having completed the meta-matrixes each question's data was displayed in either a list or in a table format. This was done for both management representatives' and worker representatives' responses. (See question 1 and question 2). As result of a restriction on space only one example of each display format is given.

\subsubsection{Data analysis: conclusion drawing/verification}

In regard to drawing and verifying conclusions Miles and Huberman (1994: 245) note that "people are meaning-finders; they can very quickly make sense of the most chaotic events". Of the utmost importance is whether the meanings the researcher finds in qualitative data are valid, repeatable and right. The abovementioned authors have suggested a number of tactics for confirming, avoiding bias and assuming the quality of conclusions of qualitative data: noting patterns, themes; seeing plausibility; clustering; making metaphors; making contrasts/comparisons; partitioning variables; subsuming particulars into the general; factoring; noting relations between variables; finding intervening variables; building a logical chain of evidence and making conceptual/ theoretical coherence. Where applicable some of these tactics were used in the discussion of results and the drawing of conclusions in the current study.

\subsection{Analysis of data and results}

Once the questionnaires were completed and the relevant documents were received, the responses of the two groups of representatives were summarised and tabulated. In a number of cases it was necessary to conduct follow-up interviews to clarify certain responses. The responses to each of the survey questions and sub-questions on the selected aspects of industrial democracy were recorded and tabulated prior to analysis. 
Table 1 Compilation of all management representatives' responses on disclosure of information

\begin{tabular}{|c|c|c|c|c|}
\hline & $\mathbf{A}$ & B & $\mathbf{C}$ & $\mathbf{D}$ \\
\hline $\begin{array}{l}\text { 1. View of } \\
\text { s16 of } \\
\text { LRA. }\end{array}$ & $\begin{array}{l}\text { Open to idea. } \\
\text { Enhances } \\
\text { consultation }\end{array}$ & $\begin{array}{l}\text { Agrees with s16 } \\
\text { as long as } \\
\text { focuses on } \\
\text { relevant info }\end{array}$ & $\begin{array}{l}\text { Only disclosed } \\
\text { if necessary to } \\
\text { assist our } \\
\text { employees }\end{array}$ & $\begin{array}{l}\text { Disclose what } \\
\text { TUs/employees } \\
\text { want if reasons } \\
\text { are justified }\end{array}$ \\
\hline $\begin{array}{l}\text { 2. Who } \\
\text { makes } \\
\text { requests } \\
\text { for DOI. }\end{array}$ & $\begin{array}{l}\text { TU reps or } \\
\text { employees }\end{array}$ & $\begin{array}{l}\text { TUs, staff } \\
\text { members WPF } \\
\text { reps. }\end{array}$ & $\begin{array}{l}\text { TUs, staff } \\
\text { members } \\
\text { WPF reps. }\end{array}$ & $\begin{array}{l}\text { Requested via } \\
\text { internal forum } \\
\text { and supported by } \\
\text { real need for } \\
\text { info. }\end{array}$ \\
\hline $\begin{array}{l}\text { 3. TU } \\
\text { limited to } \\
\text { info on } \\
\text { members } \\
\text { only }\end{array}$ & $\begin{array}{l}\text { Yes, limited TU } \\
\text { members only }\end{array}$ & $\begin{array}{l}\text { No, should have } \\
\text { clear picture of } \\
\text { organisation's } \\
\text { ability to } \\
\text { participate } \\
\text { responsibly }\end{array}$ & $\begin{array}{l}\text { Yes, non- } \\
\text { members have } \\
\text { right to confi- } \\
\text { dentiality of } \\
\text { their info. }\end{array}$ & $\begin{array}{l}\text { No, would not be } \\
\text { sufficient. A } \\
\text { thoroughly } \\
\text { thought-out } \\
\text { approach } \\
\text { implemented } \\
\text { uniformly is } \\
\text { required }\end{array}$ \\
\hline $\begin{array}{l}\text { 4. Improved } \\
\mathrm{CB} \text { and } \\
\text { conflict } \\
\text { resolution? }\end{array}$ & $\begin{array}{l}\text { Yes, positive } \\
\text { influences on } \\
\mathrm{CB} \text { and conflict } \\
\text { resolution }\end{array}$ & $\begin{array}{l}\text { Yes, better } \\
\text { understanding of } \\
\text { organisation's } \\
\text { limitations }\end{array}$ & $\begin{array}{l}\text { No, explanation } \\
\text { by management } \\
\text { usually } \\
\text { sufficient }\end{array}$ & $\begin{array}{l}\text { Not really, } \\
\text { honesty and } \\
\text { transparency not } \\
\text { appreciated by } \\
\text { TUs }\end{array}$ \\
\hline $\begin{array}{l}\text { 5. Effect on } \\
\text { employee } \\
\text { partici- } \\
\text { pation? }\end{array}$ & $\begin{array}{l}\text { Yes, positive } \\
\text { influences on } \\
\text { employee } \\
\text { participation }\end{array}$ & $\begin{array}{l}\text { Positively, } \\
\text { better } \\
\text { understanding } \\
\text { and problem- } \\
\text { solving }\end{array}$ & $\begin{array}{l}\text { Not sure if } \\
\text { disclosure has } \\
\text { had effect }\end{array}$ & $\begin{array}{l}\text { Once info is } \\
\text { received by TU } \\
\text { that is normally } \\
\text { the end of } \\
\text { request due co's } \\
\text { honesty }\end{array}$ \\
\hline $\begin{array}{l}\text { 6. Type of } \\
\text { info } \\
\text { disclosed }\end{array}$ & $\begin{array}{l}\text { All relevant } \\
\text { info. }\end{array}$ & $\begin{array}{l}\text { Salary, budget } \\
\text { strategies, all } \\
\text { management } \\
\text { info at appro- } \\
\text { priate time }\end{array}$ & $\begin{array}{l}\text { Vacancies, } \\
\text { company notices }\end{array}$ & $\begin{array}{l}\text { Non-sensitive : } \\
\text { marketing, } \\
\text { finance, } \\
\text { production, co. } \\
\text { performance etc }\end{array}$ \\
\hline $\begin{array}{l}\text { 7. Stage/ } \\
\text { when } \\
\text { disclosure } \\
\text { takes place }\end{array}$ & $\begin{array}{l}\text { When requested/ } \\
\text { deemed } \\
\text { necessary by } \\
\text { management }\end{array}$ & $\begin{array}{l}\text { When they ask } \\
\text { or when we } \\
\text { think it can } \\
\text { assist the } \\
\text { process }\end{array}$ & $\begin{array}{l}\text { Only if the } \\
\text { majority of } \\
\text { employees are in } \\
\text { agreement that } \\
\text { info is needed } \\
\text { by employees }\end{array}$ & $\begin{array}{l}\text { Need to know } \\
\text { basis. By } \\
\text { delaying dis- } \\
\text { closure it appears } \\
\text { as if info } \\
\text { becomes more } \\
\text { important to TUs }\end{array}$ \\
\hline
\end{tabular}


Table 1 continued

\begin{tabular}{|c|c|c|c|c|c|}
\hline & $\mathbf{A}$ & \multicolumn{2}{|c|}{ B } & $\mathbf{C}$ & D \\
\hline $\begin{array}{l}\text { 8. Disputes } \\
\text { re dis- } \\
\text { closure of } \\
\text { info. }\end{array}$ & $\begin{array}{l}\text { No disputes so } \\
\text { far }\end{array}$ & \multicolumn{2}{|c|}{$\begin{array}{l}\text { Not really. } \\
\text { Handled } \\
\text { in-house }\end{array}$} & No disputes & $\begin{array}{l}\text { Yes, info verified } \\
\text { by CA under } \\
\text { auspices of } \\
\text { CCMA }\end{array}$ \\
\hline \multirow{2}{*}{$\begin{array}{l}\text { 9. Resolve } \\
\text { disputes? } \\
\text { Process } \\
\text { used } \\
\end{array}$} & N/A & \multicolumn{2}{|c|}{$\begin{array}{l}\text { Negotiation } \\
\text { between em- } \\
\text { ployer and TU }\end{array}$} & N/A. & $\begin{array}{l}\text { Arbitration of } \\
\text { CCMA }\end{array}$ \\
\hline & \multicolumn{2}{|l|}{$\overline{\mathbf{E}}$} & \multicolumn{2}{|r|}{$\bar{F}$} & $\mathbf{G}$ \\
\hline $\begin{array}{l}\text { 1. View of } \\
\text { s16of } \\
\text { LRA }\end{array}$ & \multicolumn{2}{|c|}{$\begin{array}{l}\text { In terms of agreement } \\
\text { between TUs and } \\
\text { employer commu- } \\
\text { nication means } \\
\text { conveying and disclosure } \\
\text { of info at the earliest } \\
\text { possible time before } \\
\text { acting }\end{array}$} & \multicolumn{2}{|c|}{$\begin{array}{l}\text { Agree with principle } \\
\text { expressed in s16 }\end{array}$} & $\begin{array}{l}\text { We share business } \\
\text { processes and } \\
\text { financial information }\end{array}$ \\
\hline $\begin{array}{l}\text { 2. Who makes } \\
\text { requests } \\
\text { for DOI }\end{array}$ & \multicolumn{2}{|c|}{ Chairperson of WPF } & \multicolumn{2}{|c|}{$\begin{array}{l}\text { Employees and/or } \\
\text { union representatives }\end{array}$} & $\begin{array}{l}\text { The union and people } \\
\text { needing information }\end{array}$ \\
\hline $\begin{array}{l}\text { 3. TU limited } \\
\text { to info on } \\
\text { members } \\
\text { only }\end{array}$ & \multicolumn{2}{|c|}{$\begin{array}{l}\text { Yes, Personal info } \\
\text { limited to TU members. } \\
\text { Remuneration info } \\
\text { disclosed during wage } \\
\text { negotiations }\end{array}$} & \multicolumn{2}{|c|}{$\begin{array}{l}\text { Yes, info must be } \\
\text { limited to TU } \\
\text { members only }\end{array}$} & $\begin{array}{l}\text { Yes, we apply this } \\
\text { principle. The union } \\
\text { is not entitled to info. } \\
\text { re non-members }\end{array}$ \\
\hline $\begin{array}{l}\text { 4. Improved } \\
\mathrm{CB} \text { and } \\
\text { conflict } \\
\text { resolution? }\end{array}$ & \multicolumn{2}{|c|}{$\begin{array}{l}\text { Yes, LRA is silent on } \\
\text { info sharing by TU to } \\
\text { enable employer to } \\
\text { bargain/consult } \\
\text { effectively }\end{array}$} & \multicolumn{2}{|c|}{$\begin{array}{l}\text { Yes, more info is } \\
\text { available and } \\
\text { therefore better CB } \\
\text { and conflict } \\
\text { resolution }\end{array}$} & $\begin{array}{l}\text { Not at first, later it } \\
\text { improved the } \\
\text { collective bargaining } \\
\text { process }\end{array}$ \\
\hline $\begin{array}{l}\text { 5. Effect on } \\
\text { employee } \\
\text { participati } \\
\text { on? }\end{array}$ & \multicolumn{2}{|c|}{$\begin{array}{l}\text { Yes, forms part of } \\
\text { collective agreement } \\
\text { between TUs and } \\
\text { employer }\end{array}$} & \multicolumn{2}{|c|}{$\begin{array}{l}\text { Yes, employees are } \\
\text { more involved due to } \\
\text { more info available to } \\
\text { them }\end{array}$} & $\begin{array}{l}\text { No effect. Unions } \\
\text { bargained regardless } \\
\text { of info. available }\end{array}$ \\
\hline $\begin{array}{l}\text { 6. Type of } \\
\text { info } \\
\text { disclosed }\end{array}$ & \multicolumn{2}{|c|}{$\begin{array}{l}\text { All relevant info for } \\
\text { effective functioning: } \\
\text { closing/ erection of } \\
\text { plants, org. restructuring, } \\
\text { promotion of employees }\end{array}$} & \multicolumn{2}{|c|}{$\begin{array}{l}\text { Financial info during } \\
\text { wage negotiation } \\
\text { Organisational } \\
\text { restructuring }\end{array}$} & $\begin{array}{l}\text { Specific marketing, } \\
\text { financial situation, } \\
\text { monthly sales } \\
\text { estimates, } \\
\text { employment equity }\end{array}$ \\
\hline
\end{tabular}


Table 1 (continued)

\begin{tabular}{|l|l|l|l||}
\hline & \multicolumn{1}{|c|}{ E } & \multicolumn{1}{c|}{ F } & \multicolumn{1}{c||}{ G } \\
\hline $\begin{array}{l}\text { 7. Stage/when } \\
\text { disclosure } \\
\text { takes place }\end{array}$ & $\begin{array}{l}\text { Usually during wage } \\
\text { negotiations }\end{array}$ & $\begin{array}{l}\text { During wage } \\
\text { negotiations or when } \\
\text { requested }\end{array}$ & $\begin{array}{l}\text { On a continuous } \\
\text { basis or when } \\
\text { requested }\end{array}$ \\
\hline $\begin{array}{c}\text { 8. Disputes re } \\
\text { disclosure of } \\
\text { info }\end{array}$ & No disputes & $\begin{array}{l}\text { Yes, about financial } \\
\text { info }\end{array}$ & No disputes to date \\
\hline $\begin{array}{l}\text { 9. Resolve } \\
\text { disputes? } \\
\text { Process used }\end{array}$ & N/A & $\begin{array}{l}\text { Conciliation and } \\
\text { mediation at CCMA }\end{array}$ & N/A \\
\hline
\end{tabular}

Question 1. 'Respondents' views of section 16 of the LRA providing for disclosure of information."

Cases (Managements representatives' views)

A. Open to idea - enhances consultation

B. Agrees with s16 as long as focus is on relevant information

C. Only disclosed if necessary to assist our employees

D. Disclose what trade union (TU)/employees want if reasons are justified

E. In terms of agreement between TUs and employer communication means conveying and disclosure of info at earliest possible time before acting

F. Agree with principle expressed in s16 of LRA

G. We share business processes and financial information

Cases (TU/worker representatives' views)

1. In line with LRA. Means of solving disputes

2. Taken note and have made arrangements for disclosure of certain info. Not info on remuneration of senior management

3. Good idea gives workers more insight

4. It gives the TU the right to information

5. Makes protecting interests of TU members much easier

6. Very important as it allows TU reps to perform functions

7. Gives TU more information than before

From an examination of the management representatives' views on section 16 of the LRA of 1995 it is clear that all seven respondents agree with the principle of disclosure of information. However, the application of the principle differs and appears to range from an open approach of sharing information to a narrow approach of disclosing only some information and only when requested by the trade union or workers as is indicated in cases $\mathrm{C}$ and $\mathrm{D}$. 
Judging from the responses, the worker representatives are in favour of the disclosure of information. This is to be expected as the workers and their representatives now have more information available than ever before, making their job of protecting the interests of worker so much easier. Case B indicated that certain information is excluded from disclosure. This theme of reluctance to disclose certain information is repeated amongst the responses to question seven of this section.

Question 2. "Who should make such requests for disclosure of information?"

Table 2 Management representatives' responses

\begin{tabular}{|l|c|c|c|c|c|c|c|}
\hline & A & B & C & D & E & F & G \\
\hline Trade union (TU) & $\mathrm{x}$ & $\mathrm{x}$ & & & & & $\mathrm{x}$ \\
\hline Employees & $\mathrm{x}$ & $\mathrm{x}$ & $\mathrm{X}$ & & & & $\mathrm{x}$ \\
\hline TU and employees & & & & & & $\mathrm{x}$ & \\
\hline Workplace Forum & & $\mathrm{x}$ & & & $\mathrm{x}$ & & \\
\hline $\begin{array}{l}\text { Other representative } \\
\text { body }\end{array}$ & & & & $\mathrm{x}$ & & & \\
\hline
\end{tabular}

The responses of the management representatives to the question of who should make the request is presented in Table 2. No clear pattern emerges from the responses plotted in the table, but it appears that the management representatives favour the trade union and employees (or a combination of the two) in making requests for the disclosure of information.

Table 3 TU/worker representatives' responses

\begin{tabular}{|l|c|c|c|c|c|c|c|}
\hline & A & B & C & D & E & F & G \\
\hline TU Officials & $\mathrm{x}$ & $\mathrm{X}$ & $\mathrm{X}$ & & $\mathrm{x}$ & & \\
\hline Elected representatives & $\mathrm{x}$ & & & $\mathrm{x}$ & & $\mathrm{x}$ & $\mathrm{x}$ \\
\hline Councillors & $\mathrm{x}$ & & & & & & \\
\hline Individual employees & $\mathrm{x}$ & & $\mathrm{x}$ & $\mathrm{x}$ & & & \\
\hline WPF representatives & & & & & $\mathrm{x}$ & & \\
\hline Outside parties & & $\mathrm{x}$ & & & & & \\
\hline
\end{tabular}

From the responses in Table 3 it appears that worker representatives prefer that the elected or trade union representatives as well as individual employees make the requests for disclosure of information. It is interesting to note that there is 
strong agreement on this point between both management and worker representatives in spite of the fact that they serve different constituencies.

The responses to Question 3, "Should trade unions be limited to information concerning their members only?" gave the following results:

The majority of management representatives held the view that information disclosed to the unions should be restricted to information concerning their members. However, there was also a view that information should not be so restricted. A management representative was of the opinion that worker representatives "should have a clear picture of the organisation's ability to participate responsibly". Such a view may be described as mature and progressive on the role of trade unions because it recognises their particular function in healthy labour relations.

As could be expected the workers representatives, almost without exception, believed that disclosure should not be limited to information concerning members only. This was hardly surprising as more available information could strengthen their union's bargaining position. One worker representative had reservations about unrestricted access to information. This concern related to possible abuse of confidential information.

Question 4 asked "Has disclosure of information improved collective bargaining and conflict resolution processes in your organisation?" The responses of the management representatives presented a mixed picture - four reported improvement in collective bargaining and conflict resolution in their organisations and this was confirmed by the worker representatives in three of the same organisations.

The remaining three management representatives (cases C, D and E) reported that disclosure of information had not contributed to improvement in collective bargaining and conflict resolution in their organisations. This view was confirmed by four of the worker representatives, including those of organisations C, D and E. These four based their views on reasons such as that the information disclosed was too selective and too limited to be of much use.

Employee participation in decision-making is a key element of industrial democracy and Question 5 therefore asked "Has disclosure of information affected employee participation in your organisation?"

Four management representatives gave an outright positive response tot the question. This finding corresponds with that of Grosett (1997: 38) who found that one of the benefits of disclosure of information listed by employers was 
increased employee involvement. Five of the worker representatives also reported that the disclosure of information definitely improved employee participation in their organisations.

The responses from management and the worker representatives to Question 6 "What type of information is disclosed?" indicated a wide range of categories. Most frequently requested and furnished were financial information or budgetary information. Disclosure of information on organisational changes and restructuring was second most frequent.

The LRA does nor specifically indicate when information should be disclosed to a trade union or worker representatives. However, section 16(3) provides that whenever an employer is consulting or bargaining with a representative union, he must disclose all relevant information that will allow the union to engage effectively in consultation or collective bargaining. There is a similar provision in section 89(1) in respect of the functioning of workplace forums.

The responses to Question 7 "At what stage/when will your organisation disclose information to a trade union?" also demonstrated a wide variety of practices. The most common practice reported by management and by worker representatives was disclosure during wage negotiations. Other responses by management included "when deemed necessary by management", "on a need to know basis" and "when compelled by law" and "only after salary negotiations have been concluded". Ngobo and Howard (1999: 9) refer to the reluctance of employers to disclose information as "minimal compliance".

This reluctance to disclose information has the potential to cause disputes and this was probed by question 8 which asked "Has your organisation had a dispute relating to disclosure of information?" One of the worker representative stated that these disputes were "on-going - every year we experience the same kind of problems to obtain information". In contrast only two management representatives reported disputes about disclosure of information - in both cases involving financial information. A possible explanation of this dichotomy is that worker representatives experience greater frustration from management while the latter have yet to come to terms with disclosure of information as now required by the LRA.

To Question 9 "How were disputes resolved? What process was followed?" the representatives of both sides reported making use of the conciliation and/or mediation or arbitration services of the CCMA or resolving the disputes by internal negotiations between the employer and the trade union. However, the same response was given in only two cases, which is an indication of how differently matters are viewed by management and worker representatives. 


\section{CONCLUSIONS}

Bearing mind South Africa's past in which secrecy rather than disclosure of information was the norm, the strides made with the new openness regarding access to information for South African citizens can be described as quite remarkable. In the work environment, in particular, the LRA of 1995 for the first time provides for disclosure of information by employers to employees. However, there are still reluctance and resistance to providing types of information which were previously considered as belonging to the domain of management. It is believed that it will take some considerable time for the human environment to change to such an extent that it sincerely supports a culture of openness and sharing.

The study described here indicated that there is universal support amongst the participants for the principle of disclosure of information. Differences between the parties occur about the type of information to be disclosed and the timing of such disclosure. The employer side is concerned about erosion of management prerogatives and commercial confidentiality while the employee side wants information disclosure because it enhances their negotiating capacity and their ability to jointly regulate the workplace. The fact that many disputes between management and workers emanate from problems in regard to disclosure of information indicates that both sides need to work hard on developing a spirit of trust and cooperation with the other side. In view of our long history of adversarial relations this is likely to take a long time to evolve.

The study shows agreement by the parties that request for information should be made by worker representatives. From this it appears that employees are not making efficient use of Section 16 and Section 89 of the LRA which, respectively, provide that an employer must disclose all relevant information to a representative trade union or to a workplace forum to enable them to perform their functions. It is a weakness of the LRA that it is not more specific and prescriptive of when the information must be provided. The spontaneous disclosure and sharing of information by employers prior to and during collective bargaining and participation by employees in decision-making is what is required to improve and consolidate a trust relationship between employers and trade unions/employees.

Grosett (1997) found that employers reported that information disclosure were conducive to improved collective bargaining, to increased employee involvement in decision-making and to reduced conflict in their organisations. The current study produced similar responses but a significant variation is that in this instance the responses came from employer as well as employee representatives. However, worker representatives were of the view that 
insufficient information was being disclosed. This is certainly an aspect of disclosure and sharing which needs to be attended to.

It appears to be imperative for the enhancement of industrial democracy in South African organisations that a mutually acceptable procedure be developed between the national representatives of business and labour on all aspects of disclosure of information which have given or are likely in future to give rise to disputes. Greater clarity is needed, for example, on the timing of disclosure of information; on its relevance and sufficiency and on what can reasonably be expected from employers to share with their employees.

South African organisations will only achieve success and growth if suspicion and mistrust between management and labour are eradicated. One of the most powerful means of accomplishing this and then reaching mutual understanding and common objectives is the sharing of information and knowledge. It is therefor of the utmost importance that management and trade unions give urgent attention to this vital aspect of industrial relations.

\section{REFERENCES}

1 BRAND, J. \& CASSIM, N.A. (1980) "The duty to disclose - A pivotal aspect of collective bargaining" Industrial Law Journal, 1(4): 249-59.

2 BALLACE, J.R. \& GOSPEL, H.F. (1983) "Disclosure of information to trade unions: A comparative perspective" International Labour Review, 22 (1): 57-74.

3 DEVENISH, G.E. (1998) Commentary on the South African Constitution, Butterworths: Durban.

4 DU TOIT, D., WOOLFREY, D., MURPHY, J., GODFREY, S., BOSCH, D. \& CHRISTIE, S. (1998) The Labour Relations Act of 1995 ( $2^{\text {nd }}$ ed.) Butterworths: Durban.

5 DU TOIT, D., WOOLFREY, D., MURPHY, J., GODFREY, S., BOSCH, D. \& CHRISTIE, S. (2000) The Labour Relations Act of 1995, ( ${ }^{\mathrm{rd}}$ ed.) Butterworths: Durban.

6 EVERINGHAM, G.K. (1999) "Financial reporting to employees" Accounting South Africa, August: 217.

7 GROSETT, M. (1997) "Management perceptions of the effect of the disclosure of company information to employees: results of an empirical study", South African Labour Relations Journal. 21(3): 43-58.

8 INTERNATIONAL LABOUR ORGANISATION (1981) Collective Bargaining Recommendations, Geneva: ILO.

9 JOHANNESSEN, L. (1995) "A motivation for legislation on access to information", South African Law Journal. 11(2): 85-115. 
10 JORDAAN, B. (1996) "Disclosure of information in terms of the Labour Relations Act", Labour Law News, 6(1): 17-39.

11 KAHN-FREUND, O. (1977b) Labour and the Law (2 ${ }^{\text {nd }}$ ed.) Stevens: London.

12 KHOZA, F.J. (1999) "An examination of employee participation as provided for in the Labour Relations Act 66 of 1995", Unpublished masters thesis: Rhodes University: Grahamstown.

13 LANDMAN, A. (1996) "Labour rights to employee information", Contemporary Labour Law, 6(3): 32.

14 LINCOLN, Y. \& GUBA, E. (1985) Naturalistic Inquiry, CA: Sage: Beverly Hills.

15 MILES, M.B. \& HUBERMAN, A.M. (1984) Qualitative Data Analysis: A Source book of New Methods, Sage Publications: London.

16 MILES, M.B. \& HUBERMAN, A.M. (1994) Qualitative Data Analysis: A Source book of New Methods, Sage Publications: London.

17 NGCOBO, H. \& HOWARD, H. (1999) "Disclosure of information", South African Labour Bulletin, 23(6): 6-11.

18 OTTERVANGER, T.R. (1996) "Employee participation in corporate decision making: the Dutch Model" International Lawyer: 42-64.

19 ROBERTS, B.C. \& LIEBHABERG, B. (1977) "International regulation of multi-national enterprises: Trade union and management concerns", British Journal of Industrial Relations, XV(3).

20 STREEK, W. (1994) "Co-determination and trade unions", South African Labour Bulletin, 18(5): 87-95.

21 WOOD, G. \& MAHABIR, P. (2001) "South Africa's workplace forum system: A stillborn experiment in the democratisation of work", Industrial Relations Journal. 32(2): 230-43.

\section{ACTS}

22 Constitution of the Republic of South Africa Act No 108 of 1996.

23 Labour Relations Act No 66 of 1995.

24 Employment Protection Act of 1975, Legislative Series, 1975-UK 2.

25 Promotion of Access to Information Act No of 2000.

\section{CASES}

26 Atlantis Diesel Engines (Pty) Ltd v NUMSA (1993) Butterworths Law Reports. 